\title{
Akan Language
}

National Cancer Institute

\section{Source}

National Cancer Institute. Akan Language. NCI Thesaurus. Code C153830.

A Central T ano language that is the principal native language of the Akan people of Ghana, spoken over much of the southern half of that country and among some of the population of Ivory Coast. 